\title{
The ecological epoché
}

\author{
A epoché ecológica
}

Michael Barber*

\begin{abstract}
In Alfred Schutz's discussion of the world of daily life, which differs from other multiple realities, though all these realities pertain to the life-world preceding the implementation of the full-blown phenomenological reduction, he emphasizes that the world of daily life is a world of working. In this paper I will describe what working is and its potential for impairing our relationships with animals and negatively impacting ecological sustainability. I will then suggest two resources within the phenomenological tradition for challenging the potential for such impairment: Husserl's notion of empathy, which reaches to animals, and Schutz's idea of multiple realities, which, I will argue, could include a distinctive ecological attitude initiated by an ecological epoché.
\end{abstract}

Keywords: World of working. Epoché. Sustainability. Multiple realities. Empathy.

Resumo: Na discussão de Afred Schutz sobre o mundo da vida cotidiana, que difere de outras realidades múltiplas, apesar de todas essas realidades pertencerem ao mundo da vida que antecede a implementação da redução fenomenológica completa, ele enfatiza que o mundo da vida cotidiana é um mundo de trabalho. Nesse artigo, descreverei o que é trabalhar e seu potencial para prejudicar/comprometer nossas relações com os animais e impactar de forma negativa a sustentabilidade ecológica. Então, sugerirei dois recursos da tradição fenomenológica para desafiar o potencial de tal comprometimento: a noção de empatia de Husserl, que atinge os animais, e a ideia de realidades múltiplas de Schutz, a qual, como argumentarei, poderia incluir uma atitude ecológica distinta iniciada por uma epoché ecológica.

Palavras-chave: Mundo de trabalho. Epoché. Sustentabilidade. Realidades múltiplas. Empatia.

* PhD in philosophy (Yale University, New Haven, Connecticut, USA), professor at the Department of Philosophy, Saint Louis University, St. Louis, Missouri, EUA. Member of the executive council of the International Alfred Schutz Circle for Phenomenology and Interpretive Social Science, and author of The participating citizen - a biography of Alfred Schutz (New York: Suny, 2004)<michael.barber@slu.edu>. 


\section{The world of working and the human relationship with animals}

In Schutz's "The problem of personality in the social world," he argues, within the "solipsistic primordial sphere," for a pragmatic self, belonging to the world of working, which undergoes modifications, particularly with regard to its pragmatic motivations, in the worlds of phantasy, dreams, and theory (Schutz, 2013). In his later "On multiple realities," Schutz admits that the world of daily life, within which working is to be found, is thoroughly intersubjective, but, he presents the world of working as it is experienced from the subjective point of view of the actors who find themselves at the center-point of their spatial, temporal, and social coordinates. In addition, working involves action in the outer world, based upon a pragmatic project that one seeks to realize through bodily movements through which one seeks to dominate the world or master it, in contrast to the theoretical sphere, for example, whose fundamental aim is not to master the world but to observe it and possibly understand it (Schutz, 1962b).

Schutz attributes to working a unique tension of consciousness, wide-awakeness, as well as the time-perspective of the vivid present (the intersection of one's durée with cosmic time). The working self is able to bring spatial transcendences within reach, generally through bodily gearing into the world via locomotion, and it can also bring into the present, to a degree, the past through memory or the future through anticipation. In addition, one can through signs overcome the transcendence of the other person, understanding to an extent the meaning of the other's experience. However, insofar as the historical course of the other's experiences, in their order and intensity, inflects the connotation of all that the other thinks and feels and yet never coincides with one's own, one can never understand the other's meanings exactly as she understands them. Schutz observes that at the heart of our ability to bring regularly within reach what is distant is the "pragmatic idealization" of "one can always again" that Husserl described (Schutz, 2013, p. 283). This sense that I can regularly implement and re-perform previously learned action patterns, for instance, to convert an illic into a hic or to know spatially distant Contemporaries, gives me the sense of mastery basic to the world of working. Central to our pragmatic coming to terms with everyday life are the typifications we use, which, once learned, provide us with pervasive, reliable expectations about how typified objects and persons will behave and events unfold, and Schutz repeatedly insists that reliance on such typifications presupposes the 
idealizations of the "and so forth and so on" and "I can do it again" (Schutz, 2011, p. 126).

Typifications, of course, are of extreme practical importance, insofar as one can classify similar objects under a common typification, relieving oneself of the burden of having to describe each individual object separately - of course, even to describe an individual object one would have to make use of typifications, e.g. the fence that was "white" and "wooden". Instead, as Schutz notes, when we deploy typifications, we "leave out the primes," (Schutz, 1962a, p. 21) which distinguish each individual from every other one. Hence, instead of describing the experience of "going to school" in terms of all the details that make it a unique experience each day, I make use of the typification "going to school," which can be used to describe every process of going to school, confining to the horizons of one's awareness how each experience of "going to school" differs every day from every other one. This leaving out what is individual is "characteristic of typifications of all kinds," (Schutz, 1962a, p. 21) and Schutz adds that "in the natural attitude, in which the pragmatic motive dominates, these 'atypical,' namely, unique and unrepeatable aspects of experience, are in general of no interest" (Schutz and Luckmann, 1973, p. 237; see also Schutz and Luckmann,1989, p. 63, 109). Furthermore, as mentioned above, the unique histories of our individual streams of consciousness makes it such that the linguistic typifications we employ are always inflected with personal connotations that others with different histories do not share. Nevetheless, for practical purposes we overlook these differences and carry on communication which nevertheless "might be and indeed is highly successful for many good and useful purposes" (Schutz, 1962c, p. 323). In the interests of pragmatic efficacy, important aspects of human experience are simply neglected: the unique features of every situation and the limits inherent in every communication.

For pragmatic purposes, for example, one makes use of course of action types, characterizing oneself as a "post-office customer" and another person as a "post-office employee" with whom one engages in mutually interlocked behavioral patterns that leave out the individuality of both parties (Schutz, 1962a, p. 25-26). Such anonymizing of our mutual individuality is absolutely necessary for pragmatic survival in modern society, and there is nothing per se immoral in doing so. In fact, Schutz argues that business persons have to adjust their behaviors and intrinsic relevances to the imposed relevances to be found in competitors and clients just as chess players must reconfigure their intrinsic relevances in the face of the relevances experienced as imposed by their partners, typified in the role of co-chess-players. The idea that the other's 
intrinsic relevances constitute imposed relevances upon oneself and one's own set of intrinsic relevances suggests the independence of the other who cannot be merely subjugated under one's relevances. The mere typification of someone else for my own pragmatic purposes need not issue in any injustice against another person, as Schutz (1964) suggests in his essay on equality. However, we know from experience that the reconfiguration of one's intrinsic relevances in the face of the imposed relevances of the other can involve strategies for dominating the other, depriving him or her of her autonomy, or acting toward others so that they "become alienated from themselves or are treated as mere interchangeable representatives of the typified traits and characteristics" (Schutz, 1964, p. 261; see also Schutz, 1962a, p. 25-26; Schutz, 2011).

The danger of the domination of others is particularly acute in everyday life reality in which one's pragmatic relevances to guarantee one's survival and to ensure that one can effectively, efficiently, and successfully master one's reality predominate. How easily it would be to neglect the autonomy of others and the respect due them in a context in which, because of urgent pragmatic imperatives, one already simply overlooks what is individual in persons, events, and situations and already disregards the limits to understanding and communication that underlie our supposedly smooth implementation of communicative processes every day.

But pragmatic relevances also play an important role in issues of sustainability, particularly affecting our relationships with animals. For instance, it has been documented that there are numerous gigantic feed lots containing as many as two hundred thousand cows and pigs "crammed in together, shoulder to should, standing knee-deep in their own excrement, and in some case fed ground-up carcasses of other cows and pigs." (Martin, 2008, p. 258; see also Martin, 2008, p.207, 265). Furthermore, there are reports about chickens similarly crowded for their entire lifetimes into cages with little room to stand, such as two-thirds of a square foot in some cases, or being fed hormones so that their breasts will grow very large (such that if humans grew at the same rate they would weigh 660 pounds at eight weeks of age and such that these chickens are unable to stand up). One can see these animals as the victims of pragmatic human relevances that call for the efficient, mass-produced, low-cost processing of food for rapid human consumption. Such pressing pragmatic relevances, which, as we have seen, originate with the ego agens centered on itself as the 0 -point of all its coordinates and which in everyday life already lead us to overlook important aspects of human experience, seem unconstrained by the least thought about how these animals must experience their lives. Indeed, other threats to the environment, nature, and sustainability 
in general grow out of such uncurbed pragmatic relevances, whose impacts are often anonymous, often far distant and out of sight, with respect to those, for example, who consume chicken or steak dinners or whose everyday activities depend on sources of energy whose usage may be environmentally destructive. Phenomenology can make a distinctive contribution by highlighting that the higher-level pragmatic concerns, governing the food-processing industry, which at times can seem narrowly focused and oblivious to wider horizons, can be traced back to simpler, pragmatic relevances. Such simpler relevances pervasively govern the ego agens, which simply cannot dispense with typical patterns it has learned and which survives on the basis of such patterns and the sense accompanying then that "I can do it again," which is necessary for mastering everyday life situations and surviving (Kristof, 2014, p. 31).

\section{Offsetting working relevances: animal empathy}

There are resources within Schutzian and Husserlian phenomenology to counter the obliviousness to the perspective of animals to which pragmatic emphases might be prone. In the first place, Husserl's notion of empathy (Einfühlung) encompasses our relationships with animals and can issue in a kind of solidarity with them. Husserl is clear that I establish an empathetic (in the sense of a "cognitive-recognizing") connection with another "I" pretheoretically, since empathy with regard to the other person does not have to be reflective (Husserl, 1973a, p. 431-432). I do not have originary experience of the other's consciousness (as I do my own), but I must always resort to representation (Vergegenwärtigung) through which the other's consciousness is experienced as "co-present" (mitgegenwärtig) (Husserl, 1973a). I can see another governing (waltende) in its body similar to the way in which I do with my own (Husserl, 1973b) and, via a passive association, a "pairing" (Paarung) (Husserl, 1973c), ${ }^{1}$ on the basis of this similarity, I "perceive" (wahrnehmen) (Husserl, 1973a), directly, without inference or theorizing, the other as a bodily-spiritual (leiblich-geistig) subject similar to myself (Husserl, 1973a). I apperceptively bring to bear my past experience (especially my own bodiliness) on other subjects like me in their bodiliness, which then appresents their innerness, their spiritual character; such an appresentation belongs to every apperception of another similar to myself (Husserl, 1973b). Husserl is clear that such empathy is not a matter of me projecting myself (extrajiziert) (Husserl, 1973b) into the other insofar as Husserl repeatedly claims that it is

\footnotetext{
${ }^{1}$ Dorion Cairns (2012, p.57) observes that "the fundamental tendencies of mental life are tendencies to identify and assimilate".
} 
the other's bodiliness (Leiblichkeit) (Husserl, 1973a) that awakens (Husserl, 1973b) or stirs up (Husserl, 1973a) my empathic response (Husserl, 1973b). Similarly empathy must be seen as a distinctive experience (Husserl, 1973b), although it is comparable to other experiences in which one experience an "I" that is other than itself, although it might not be the I of a distinct individual person over against me. For instance, in memory of my past, for example, I re-represent (wiedervergegenwärtige) (Husserl, 1973a) a past "I" (that is nevertheless given as past) (Husserl, 1973c), with which my present I is both ontologically identical (Husserl, 1973a) and yet temporally different (Husserl, 1973c). Similarly, empathy resembles phantasy in which I can transpose an "I" (a version of myself or another), fictively constituted as belonging to an inactual present or an inactual past, in the mode of "as if" or "quasiness," (Husserl, 1973a) unconstrained by the other's bodiliness which, by contrast, limits the free deployment of imagination in the case of empathy (Husserl, 1973c). Further, empathy with regard to another distinct from myself is not merely a matter of anticipation, since one continually experiences confirmation (though not through originary experience) as the other's behavior conforms over and over again with what one would expect of another subject (Husserl, 1973b).

Husserl extends empathy to organic essences on the basis of the assimilation between my body and that of the multi-membered body of another in which an "I" governs - an extension that he sees providing a foundation for biological science.

The behavior of the body (Körpers) over there, with respect to its bodily movement, such as an outstretched hand, etc., reminds me of myself, as if I were there, and [as if] I would set myself in motion kinesthetically and stick my hand out to grasp the thing, the stick, there. The further movement, which I would again initiate for myself and which would be transferred apperceptively, is of just the type that the body there carries out. In this mobile, unfolding representation under continual fulfillment of the always preindicated representations, a unity is constituted of representations, which are multi-faceted, intentionally bound up with each other and founded in each other, and these representations appear as those of [self-] governance (Waltens) and of an "I" governing [in its body] (Husserl, 1973c, p. 256-257). ${ }^{2}$

\footnotetext{
${ }^{2}$ See also Husserl (1954) in which he claims that the understanding of the biological itself and animal empathy are the guide to biological science. See also, in this regard, Merleau-Ponty (1970).
} 
Through a kind of genetic dismantling (or Abbau), I can imaginatively separate out layers of experience, for instance, allowing that the child might see the same thing that I do, but not with fully educated apperceptive contributions, the higher-level horizons, and the organizational capacities that I as an adult would bring to bear on seeing that same thing - and the a similar Abbau can be exercised with animals. Hence, excluding possibilities for kinesthetic movement, we can interpret the animal as seeing on an optical level a thing in much the way we might, and one can expect a confirmation of this imputation of such seeing to the animal if it, on a higher level, engages in behavior toward that object similar to what humans would implement regarding this same thing. The bodyliness of higher animal species differs from our own, but perhaps least so in the case of apes to which we are most similar. With regard to apes, one widens the apperceptive indications through an alteration of the analogy that assimilates our bodies with others' like our own. Hence, we can associate the movement of the grasping organs of apes with our own (as the above example of reaching for a stick suggests), insofar as apes utilize their hands to seize things as we do, even though they also walk on their hands and grab things with their feet (and they have a tail, which does not compare with anything in our experience). For lower animals the ontological indications for an analogy are minimal, but even there there is some analogy with our bodiliness which is "apperceptively powerful (kräftig)." Husserl points to the sensibility of the skin and its reactive movements, which lower-level animals exhibit when their skin is pricked and they wince or quiver similarly to the way in which we frown automatically upon being touched in a way that is uncomfortable. These analogies permit empathy even with regard to lower level animals, and one could even think of worms or insects in this regard (Husserl, 1973b).

Long before we reflect, we already automatically attribute to animals at many different levels a consciousness of their own that is similar to ours, however much we might theoretically deny this commonality (e.g., thinking of them as mere machines responding to stimuli with no consciousness of their own) or simply ignore it by disregarding the brutality often found in the food processing industry and not even considering how they might experience such constrained lives. Given the foundational empathic analogies already drawn, including the way that worms might react to being pricked as we might, one might wonder whether animals experience such industrial cruelty in ways similar to how we would. Furthermore, the fact that empathy relies on passive syntheses that operate immediately suggests that it would also be possible to link via other forms of passive synthesis distinctive animals or animals far distant from each other. Hence, one might associate the pets we are fond of or 
the animals in the zoo we interact with - whose consciousness and similarity to ourselves is immediately recognized - with those far distant animals, as kinds of contemporaries, which are subjected to the anonymous harms that the industrial pursuit of pragmatic efficacy imposes upon them. Such passive linkages can be unsettling long before one raises, addresses, or resolves moral or theoretical questions regarding our treatment of animals.

\section{The ecological epoché}

Schutz, who has perhaps described everyday reality and in particular the pragmatic world of working better than anyone else, also suggests nonpragmatic multiple realities as alternatives to the world of working. Via what he calls "epochés," analogous to the phenomenological epoché, one enters such provinces of meaning, including dreaming, phantasy, theory, literature, drama, aesthetic enjoyment, or religion, in which the pragmatic motives governing the world of working no longer hold sway. Examples of the epochés that break one free from working's pragmatic imperatives and that are the gateway into non-pragmatic provinces of meaning include the following: one falls asleep and starts dreaming, a child leaps with another child in the world of play, the curtain opens and the play starts, one enters a temple and the presence of the transcendent overtakes one, or one encounters a beautiful work of art or gorgeous landscape and one is overcome with a sense of awe or enjoyment. In many ways, the Schutzian understanding of the guiding relevances in the non-pragmatic finite provinces of meaning converges with Aristotle's idea that philosophy, which serves no practical purpose and pertains to the world of scientific theory, begins in the feeling of wonder (Schutz, 1962b; Aristotle, 1963).

Animals engage in certain behaviors that evoke wonder in us; that jolt us out of the everyday world, its pragmatic purposes, and the pragmatic, taken for granted typifications of animals that we rely on unreflectively; and that effect a kind of epoché in us that I will call the "ecological epoché," in which we regard nature and our relationships with animals with a sense of wonder and even awe, more like what one might find within the religious or aesthetic attitudes.

For example, a friend of mine had a small dog that was pregnant with pups, and, and, while he was at work, the dog began to deliver its pups, and my friend advised a nephew who was living in his home to open the dog's cage door and make sure that the dog had sufficient water. When my friend returned from work he discovered that the dog had carried each of the pups down the hall through the living room and into my friend's bedroom where she left them. 
I was stunned to hear about this behavior and have often asked myself what the dog might have meant by this action. Did she think that her pups would be safest in her owner's room? Was she making of her pups a gift to her owner?

Ethologist Frans De Waal recounts numerous examples of animal behavior that arouse the amazement typical of the ecological epoché. He describes, example, how experimenters hung fruit from a ceiling and placed a stick near an elephant in the room to see if it might use the stick to knock down the fruit. Since the elephant did not use its trunk to pick up the stick and bat down the fruit that it could not reach, scientists concluded that elephants lacked practical intelligence in the elephant-in comparison with Kohler's monkeys that arranged boxes and relied on sticks to reach distant food. However when other scientists reconfigured the experiment and put a small box in the room, the elephant slowly kicked the box to a position under the fruit, stood on the box with its front legs, and reached the fruit with its trunk. The attribution of lack of intelligence was the scientists' error, for failing to understand the particular way that that elephant exercised its practical intelligence. This experiment, revealing how our own preconceptions might dispose us to underestimate animal intelligence (here elephants), can shock us into recognizing that animals may be possessed of a greater intelligence than we ever imagined (De Waal, 2016).

De Waal (2016) describes numerous awe-inducing experiences of animals that place one within the ecological attitude: monkeys anticipating the future, echolocation among bats, the unique dances bees deploy to indicate the presence of food, feline communication through rubbing up against cage walls, kissing behaviors as a welcoming sign among bonobos, the counting behavior of horses, apes who jump into lakes to save others even though apes do not swim, macaques' learning to wash sweet potatoes because a predecessor had done so, chimpanzees passing over hidden food and returning to it later when no other chimps were in the area, young chimps bringing water to debilitated animals, face-recognition among wasps, chimpanzees developing five different kinds of tools for different purposes, crows' utilization of tools, ape mourning, alpha male gorillas rescuing a choking juvenile gorilla, a chimpanzee demonstrating its newborn to an experimenter, alpha male chimpanzee political strategies and their abilities to recognize the friends of opponents, female apes reconciling conflicting males, joint coordinated behavior among apes and elephants, joint attention among orca whales, trout/eel shared expeditions to find food sources, bonobos carrying rocks a long distance to crack nuts, male apes grooming followers the day before attacking enemies, dolphins delaying action until more information was available, and male cuttle fish showing themselves in 
two different colors at the same time, one color on the side facing a female fish and the other facing male enemies (De Waal, 2016).

In the end, De Waal admits that ethologists like himself have often been called "naïve, romantic, soft, unscientific, anthropomorphic, anecdotal, or just a sloppy thinker," (De Waal, 2016, p. 265) and consequently he welcomes the criticisms of skeptics and insists on the need for experimental evidence for claims (De Waal, 2016). It is as though De Waal has entered a sphere of experience through the ecological epoché in which wonder is evoked or an empathetic linkage to animals is stirred up, but he recognizes at the same time the need for a theoretical evaluation of what he is experiencing. A similar pattern appears when one enters the religious or aesthetic provinces of meaning. One experiences awe or is taken up with beauty, but feels the need for theoretical exploration or critique and may resort to the theoretical province of meaning or to some enclave in which religion and the appreciation of beauty overlap with theory. Theology and art criticism or art theory are born out of experiences within a province of meaning that precedes them and is distinctive from them. Such parallels suggest how the ecological attitude itself constitute a specific attitude all its own, akin to the religious or aesthetic attitudes, and yet needing theoretical examination about the scientific or moral justifiability of what one experiences and how one ought to proceed.

Finally, phenomenology provides an apt philosophical framework for understanding how the world of working lies at the root of many of the questions of sustainability, particularly those that our treatment of animals raise. It can also explain our connections to animals and the wonder we experience in our relationships with them. It can point to the ecological epoché and attitude we enter through it-whatever theoretical conclusions we may eventually reach about the questions that attitude itself generates.

\section{References}

ARISTOTLE. Metaphysics. In: The philosophy of Aristotle. New York: New American Library, 1963.

CAIRNS, Dorion. Applications of the theory of sense-transfer. In: Lester Embree (ed.). Animism, adumbration, willing and wisdom: studies in the phenomenology of Dorion Cairns. Bucharest: Zeta-Books, 2012.

DE WAAL, Frans. Are we smart enough to know how smart animals are? New York: W.W. Norton and Company, 2016.

HUSSERL, Edmund. Die Krisis der Europäischen Wissenschaften und die Transzendentale Phänomenologie. In: Walter Bieme (ed.). Husserliana. The Hague: Martinus Nijhoff, 1954. 
HUSSERL, Edmund. Zur Phänomenologie der Intersubjektivität - Texte aus dem Nachlass, Erster Teil: 1905-1920. v. XIII. In: Iso Kern (ed.). Husserliana. The Hague: Martinus Nijhoff, 1973a.

HUSSERL, Edmund. Zur Phänomenologie der Intersubjektivität - Texte aus dem Nachlass, Zweiter Teil: 1921-1928. In: Iso Kern (ed.). Husserliana. The Hague: Martinus Nijhoff, $1973 \mathrm{~b}$.

HUSSERL, Edmund. Zur Phänomenologie der Intersubjektivität - Texte aus dem Nachlass, Dritter Teil, 1929-1935. v. XV. In: Iso Kern (ed.). Husserliana. The Hague: Martinus Nijhoff, 1973c.

KRISTOF, Nicholas. Abusing chickens we eat. In: The New York Times, Dec. 4, 2014.

MARTIN, Bill. Ethical Marxism: the categorical imperative of liberation. Illinois: Open Court, 2008.

MERLEAU-PONTY, Maurice. Themes from the lectures at the College de France 1952-1960. Evanston: Northwestern University Press, 1970.

SCHUTZ, Alfred. Common-sense and scientific interpretation of human action. In: Maurice Natanson (ed.). Collected papers I: The problem of social reality. The Hague: Martinus Nijhoff, 1962a.

SCHUTZ, Alfred. On multiple realities. In: Maurice Natanson (ed.). Collected Papers I: The problem of social reality. The Hague: Martinus Nijhoff, $1962 \mathrm{~b}$.

SCHUTZ, Alfred. Symbol, reality, and society. In: Maurice Natanson (ed.). Collected Papers I: The problem of social reality. The Hague: Martinus Nijhoff, 1962c.

SCHUTZ, Alfred. Equality and the meaning structure of the social world. In: Arvid Brodersen (ed.). Collected Papers II: Studies in social theory. The Hague: Martinus Nijhoff, 1964.

SCHUTZ, Alfred. Reflections on the problem of relevance. In: Lester Embree (ed.). Collected Papers 5: Phenomenology and the Social Sciences. Dordrecht: Springer, 2011.

SCHUTZ, Alfred. The problem of personality in the social world. In: Michael Barber (ed.). Collected Papers VI: Literary reality and literary relationships. Dordrecht: Springer, 2013.

SCHUTZ, Alfred; LUCKMANN, Thomas. The structures of the life-world. Evanston: Northwestern University Press, 1973.

SCHUTZ, Alfred; LUCKMANN, Thomas. The structures of the life-world. Evanston: Northwestern University Press, 1989.

Received: 28 June 2017

Aproved: 29 Sept. 2017

Correspondent autor:

Michael Barber

Department of Philosophy

Saint Louis University

Adorjan Hall 130

3800 Lindell, St. Louis

Missouri 63108, USA 